\title{
Effective protection of fish on inshore coral reefs depends on the scale of mangrove-reef connectivity
}

\author{
Tyson S. H. Martin ${ }^{1, *}$, Andrew D. Olds ${ }^{1,2}$, Kylie A. Pitt ${ }^{1}$, Alana B. Johnston ${ }^{1}$, \\ Ian R. Butler ${ }^{3}$, Paul S. Maxwell ${ }^{1}$, Rod M. Connolly ${ }^{1}$ \\ ${ }^{1}$ Australian Rivers Institute - Coast and Estuaries, and School of Environment, Griffith University, Gold Coast, QLD 4222, Australia \\ ${ }^{2}$ School of Science and Engineering, University of the Sunshine Coast, Maroochydore, QLD 4558, Australia \\ ${ }^{3}$ Australian Research Council Centre of Excellence for Coral Reef Studies, School of Biological Sciences, \\ The University of Queensland, St Lucia, QLD 4072, Australia
}

\begin{abstract}
Connectivity is an important consideration in conservation, but is rarely quantified when assessing marine reserve performance. Mangrove-reef connectivity is known to enhance reserve effectiveness when habitats are close together $(<250 \mathrm{~m}$ apart). Coral reefs are, however, often farther from mangroves, making it difficult to integrate mangrove-reef connectivity into conservation more widely. To determine if connectivity affects reserve performance beyond $250 \mathrm{~m}$, we examined effects on reef fish in Hervey Bay, Queensland, Australia. Reserves affected fish assemblages and enhanced the abundances of harvested species and key functional groups on reefs within $500 \mathrm{~m}$ of mangroves (about 10 times greater inside reserves), but not on isolated reefs. Connectivity can affect reserve performance over broader distances than previously shown. We suggest that connectivity effects on inshore reef fish may simply be amplified on reefs located closest to adjacent mangroves, provided those reefs are within the migratory capabilities of fish. Mangrove-reef connectivity should be viewed as an important conservation target and may be broadly incorporated into reserve design by prioritizing the protection of seascapes where mangroves and reefs are closest.
\end{abstract}

KEY WORDS: Australia $\cdot$ Conservation planning $\cdot$ Coral reef $\cdot$ Fish $\cdot$ Seascape ecology $\cdot$ Mangrove $\cdot$ Marine reserve $\cdot$ Scale

Resale or republication not permitted without written consent of the publisher

\section{INTRODUCTION}

Maintaining and enhancing biodiversity and ecosystem functioning is now the primary focus for conservation (Estes et al. 2011). The functioning of ecosystems may be enhanced by the services of mobile organisms, which link important ecological processes across landscapes (Nystrom \& Folke 2001). These connecting movements can influence the distribution and abundance of biota and, consequently, the capacity of ecosystems to cope with disturbance (Lindenmayer et al. 2008). Ecological connectivity is, therefore, gaining acceptance as an important consideration in conservation planning and ecosystem- based management (Grober-Dunsmore et al. 2009, Hodgson et al. 2009, McCook et al. 2009, Magris et al. 2014).

Connectivity is a function of habitat area, quality, spatial arrangement, and the mobility and dispersal capabilities of individual species (Hodgson et al. 2009, Olds et al. 2012a). The term is frequently used to describe the biological and physical linking of populations, communities, habitats, or ecosystems through space (Lindenmayer et al. 2008); for example, the movement of animals from juvenile to adult habitats (e.g. Gillanders et al. 2003) and the dispersal of seeds and propagules by wind or water (e.g. Soons et al. 2004). Connectivity can affect the dispersal of 
populations (Mora et al. 2012), the composition of assemblages (Warfe et al. 2013), and the health and recovery of disturbed ecosystems (Mumby \& Hastings 2008). Connectivity can, however, also be difficult to conceptualise (Beger et al. 2010a), but fortunately can be quantified simply using a variety of spatial pattern metrics (e.g. habitat isolation, area and proximity), which are straightforward to incorporate into conservation planning (Calabrese \& Fagan 2004, Wedding et al. 2011).

In marine ecosystems, connectivity is thought to depend on the physical (e.g. tides and currents; Krumme 2009, Hyndes et al. 2014) and biological (e.g. movements of fish and decapods; Haywood \& Kenyon 2009, Sheaves et al. 2015) properties of ecosystems. In tropical seascapes, links between coral reef, mangrove and seagrass habitats are particularly important for mobile organisms, such as fish, which move among habitats to spawn, disperse, feed and seek refuge from predators (e.g. Nagelkerken 2009, Sheaves 2009, Igulu et al. 2014). These connections also promote the abundance of important functional groups and key ecological processes (e.g. herbivory, predation and nutrient enrichment) in coral reef seascapes (Olds et al. 2012a, Peterson et al. 2013). This effect of connectivity on ecological processes can help promote reef health and resilience (McCook et al. 2009), and is the reason seascape connectivity (i.e. these spatial links among reefs, mangroves and seagrasses) is incorporated into marine spatial planning (Huijbers et al. 2015). Connectivity with mangroves has recently been shown to enhance the performance of marine reserves in the Caribbean Sea (Nagelkerken et al. 2012) and western Pacific Ocean (Olds et al. 2013). Little is known, however, about the scale over which these connectivity effects can enhance reserve performance (Pittman \& Olds 2014).

Fish move between coral reef and adjacent habitats over both short (e.g. daily foraging movements) and long (e.g. ontogenetic migrations) timescales (Pittman \& McAlpine 2003). This movement can, however, vary among species with differing mobility and may also differ across seascapes of differing habitat arrangements, meaning that it can be difficult to incorporate connectivity into conservation plans without region-specific data. Many studies have assessed the importance of adjacent habitats to fish on coral reefs (e.g. Mumby et al. 2004), but studies that investigate the impact of scale on seascape connectivity are rare. An exception is the study by Olds et al. (2013), who showed that at 3 locations across the western Pacific Ocean, mangrove-reef connectivity can affect fish populations and the performance of marine reserves where these habitats fringe islands and are separated by $<250 \mathrm{~m}$. It is not known if similar connectivity effects also occur in seascapes with greater isolation between these habitats. Recent reviews, such as that by Berkstrom et al. (2012), suggest that there may be a consistent, general threshold for seascape connectivity at a scale of hundreds to thousands of metres, but that we lack empirical data to test this assertion.

We utilised another location in the western Pacific Ocean, the Great Sandy Marine Park (GSMP) in Hervey Bay, Australia, to test the effect of greater isolation between mangroves and reefs on the performance of marine reserves. The GSMP contains fringing coral reef communities (Zann 2012, Butler et al. 2013) and mangroves that occur at greater distances from adjacent coral reefs than those studied in other locations by Olds et al. (2013). This allowed us to investigate the influence of mangrove-reef connectivity on reserve performance across a larger scale than previously tested. We examined the broader importance of mangrove-reef connectivity for conservation by testing the hypothesis that, despite greater distances between coral reefs and mangroves across the region (compared to those studied by Olds et al. 2013), reserves close to mangroves would perform better than those distant from mangroves.

\section{METHODS}

\section{Seascape analysis}

We surveyed the assemblages of coral reef fish in May and June 2013 at every fringing coral reef site in the Hervey Bay region (15 sites in total). These sites were split across 2 locations (Great Sandy and Woongarra Coast) in the GSMP (Fig. 1). Both locations supported seascapes where fringing coral reefs were located seaward of adjacent mangroves. These reef and mangrove habitats were separated by expansive, intertidal flats of sand/rubble. We compared fish assemblages between 6 marine reserve sites (protected since 2006) and 9 unprotected control sites (Table S1 in the Supplement at www.int-res.com/ articles/suppl/m527p157_supp.pdf). Marine reserves were all 'Marine National Park Zones', where harvesting activities such as recreational and commercial fishing are not permitted, but diving and boating are allowed (DNPRSR 2012).

Mangrove-reef connectivity was quantified from existing benthic habitat maps using ArcGIS (ESRI) as the edge-to-edge distance between mangrove and 


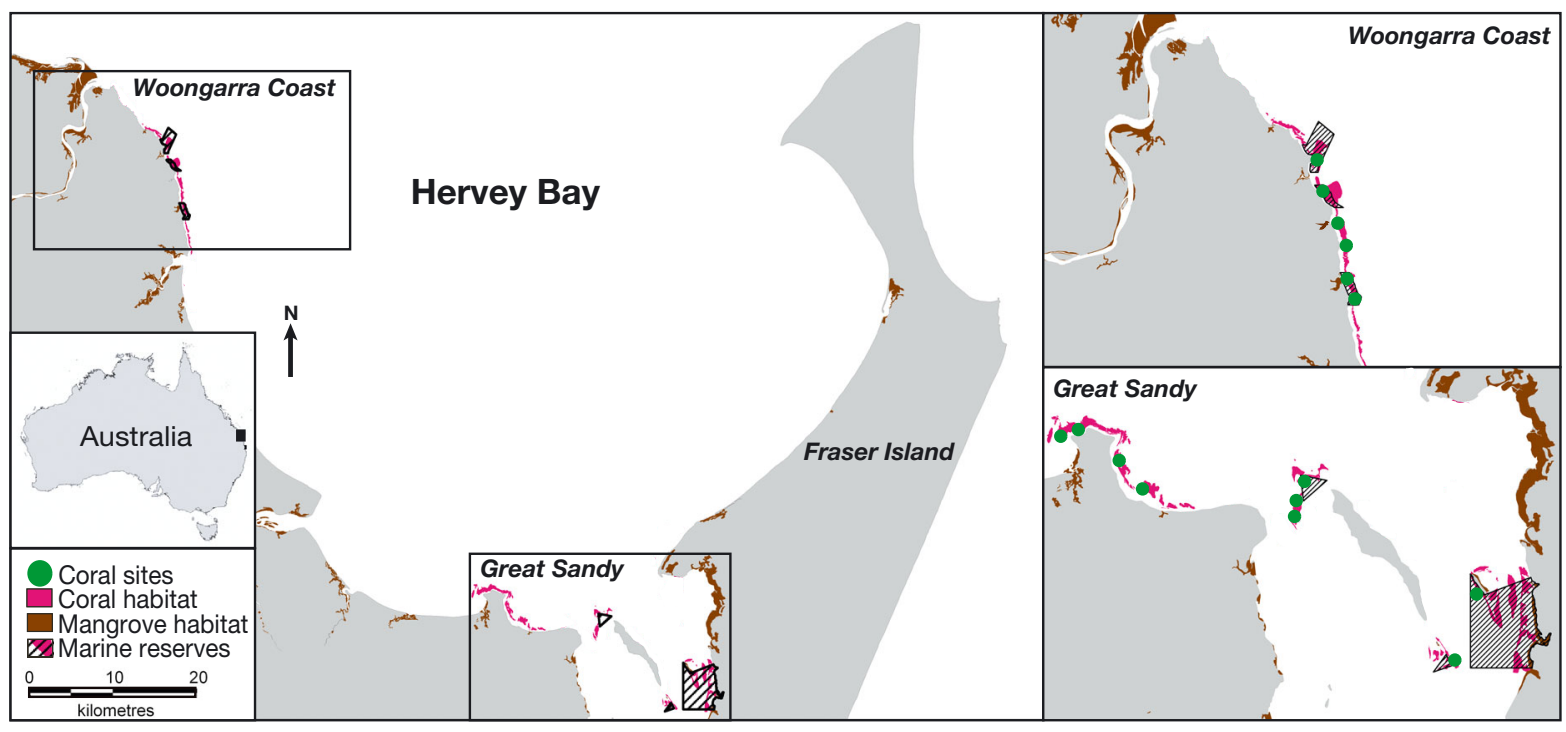

Fig. 1. Mangroves and fringing coral reefs in Hervey Bay, Australia. Green circles: survey sites

coral reef habitats (following Olds et al. 2012b). Distances between mangrove and coral reef habitats in the study area are larger than those examined in similar seascapes elsewhere in the Pacific Ocean (see Olds et al. 2013). We surveyed every major reef in the region, and all reefs had their inshore edge located either $<500$ or $>1000 \mathrm{~m}$ from mangroves (Fig. S1 in the Supplement at www.int-res.com/articles/suppl/ m527p157_supp.pdf). The absence of reefs in the intermediate range effectively precluded the use of a regression style analysis using distance to mangroves as a scale variable as the lack of data between these distances means that any trends that would come from a regression style analysis would be purely speculative between the missing distances. Instead, to investigate the potential interactive effects of mangrove connectivity on marine reserve performance, mangrove connectivity was allocated to 2 distinct categories based on the natural distribution of habitats in the study area. Coral reef sites within $500 \mathrm{~m}$ of mangroves were classified as 'near', whereas 'far' coral reef sites were $>1000 \mathrm{~m}$ from mangroves. This provided a simple way to test the influence of larger distances between coral reefs and adjacent mangroves and, therefore, investigate the interactive effects of connectivity and reserves across a broader scale than previously tested.

\section{Fish assemblages}

Underwater visual census was used to survey fish on coral reefs. To maximise our chance of detecting joint connectivity and reserve effects, our sampling was restricted to the austral winter. The focal species of interest are most active and abundant at this time (e.g. Sparidae; Ferrell \& Sumpton 1997), and local weather conditions (i.e. rainfall, wind and visibility) prevent visual surveys from being conducted in other seasons. Each site was surveyed within $3 \mathrm{~h}$ of low tide (when mangroves were dry and not accessible to fish) along 5 replicate $50 \times 4 \mathrm{~m}$ transects, with transects separated by a minimum of $50 \mathrm{~m}$ (following Olds et al. 2012b). Transects were positioned on the reef slope, at depths of 1 to $3 \mathrm{~m}$ below Lowest Astronomical Tide, and surveyed by the same diver. All fish $>5 \mathrm{~cm}$ total length were recorded, identified to species, and their sizes were estimated. Fish assemblages were organised into the following groups: harvested species, herbivores, piscivores and prey fish. These categories are not mutually exclusive, as herbivorous and piscivorous fish are harvested in the region. Commercial and recreational fishing data were used to identify locally harvested species, and dietary information was used to assign fish to functional groups (Froese \& Pauly 2000). Herbivores included members of the families Acanthuridae, Kyphosidae, Pomacanthidae, Scaridae and Siganidae (following Choat et al. 2002). These families contain roving herbivorous fish, which are those most likely to move among habitats. Piscivores included members of the families Lutjanidae, Platycephalidae, Scomberidae, Serranidae, Sparidae and Sphyraenidae (Baker \& Sheaves 2005). Density of prey fish was based on the abundance of Atherinomorus vaigiensis (common hardyhead) and Gerres subfasciatus (silver 
biddy), which are abundant and common prey species that move tidally between mangroves and subtropical coral reefs (Olds et al. 2012b). Full lists of species included in each functional group are listed in Table S2.

\section{Quantifying habitat complexity and fishing pressure}

As spatial patterns in ecology can only infer causality after attempting to falsify other potential explanations (Mumby et al. 2004, Olds et al. 2012b), data on hard coral cover (which may influence fish assemblages) were collected and analysed for consistency with observed patterns in fish assemblages. To quantify coral cover, digital photographs of the substrate were taken every $1 \mathrm{~m}$ along each fish-survey-transect (from $0.5 \mathrm{~m}$ above the substrate) and the cover of hard coral in each image was quantified using Coral Point Count (Kohler \& Gill 2006)

Coastal boat ramps are often located in sheltered waters, which are, therefore, also likely to support mangroves. Subsequently, it is possible that metrics such as distance to boat ramp and distance to mangroves may be correlated. However, due to the complex nature of the seascape in Hervey Bay, which contains many creeks and rivers interspersed throughout the bay, distance to nearest boat ramp and distance to nearest mangroves were not correlated (Table S3). To verify that patterns in fish abundance were not driven by spatial variation in fishing pressure, the distance of each reef from the nearest boat ramp (following Stuart-Smith et al. 2008) was measured using ArcGIS.

\section{Data analysis}

Permutational multivariate analysis of variance (PERMANOVA) tests the simultaneous response of 1 or more variables to 1 or more factors in an ANOVAbased experimental design (Anderson et al. 2008) and was used to assess the influence of reserve status (reserve vs. fished), mangrove-reef connectivity (near vs. far), location (Great Sandy vs. Woongarra Coast), distance to nearest boat ramp (covariate) and hard coral cover (covariate) on reef fish assemblages. Reserve status, mangrove-reef connectivity and location were fixed, orthogonal factors. Factors not found to be near significance $(p>0.25)$ were then removed from the experimental design to increase statistical power and to further explore the relation- ships between the remaining influential factors (for results of full experimental design including all factors for fish abundances, see Tables S4 \& S5). Multivariate analyses were based on modified Gower (log base 2) similarity measures, which exclude joint absences, strongly emphasise differences in species abundance and are appropriate for dealing with multivariate heterogeneity of variance (Anderson et al. 2011). Canonical analysis of principal coordinates (CAP) was then used to visualise the effects of significant interacting factors following PERMANOVA (Anderson \& Willis 2003). Separate univariate PERMANOVA tests using the same design were run on fish abundance in each functional group, after log transformation to reduce heterogeneity of variances. A posteriori pairwise tests were applied to significant interacting factors. (Anderson et al. 2008).

\section{RESULTS}

Mangrove-reef connectivity influenced the effect of reserves on coral reef fish assemblages $(p=0.004)$ (Table 1). Reserve reefs near mangroves supported different fish assemblages to fished reefs near mangroves ( $\mathrm{p}<0.001)$, but assemblages did not differ between reserve and fished reefs that were far from mangroves $(p=0.310)$ (Table 1$)$. Differences in assemblage composition between reserve and fished reefs near mangroves were driven by herbivores (Siganus fuscescens and Abudeduf bengalensis), piscivores (Acanthopagrus australis and Lutjanus russelli) and prey fish (Gerres subfasciatus and Atherinomorus vaigiensis), which were abundant on reserve reefs near mangroves (Fig. 2).

Reserves only enhanced fish abundances when reefs were near to mangroves. There was no effect of reserves on reefs far from mangroves. PERMANOVA, and the subsequent pairwise testing of significant interactions, revealed that harvested $(\mathrm{p}=$ $0.003)$, herbivorous $(p=0.047)$, prey $(p<0.016)$ and piscivorous $(p=0.001)$ fish were between 4 and 14 times more abundant on reserve than fished reefs, but only when near to mangroves (Fig. 3, Table 2 and Tables S4 \& S5 in the Supplement).

The effect of location on assemblages of fish varied between status ( $p=0.005)$ and mangrove-reef connectivity ( $p=0.010$ ) (Table 1 and Fig. S2 in the Supplement at www.int-res.com/articles/suppl/m527 p157_supp.pdf), but not for fish abundances (Table 2 and Tables S4 \& S5 in the Supplement). Differences in species composition between the 2 locations, therefore, probably caused location to interact with status 
Table 1. Summary of permutational multivariate analysis of variance (PERMANOVA) results examining spatial variation in the composition of coral reef fish assemblages. GS: Great Sandy location; WC: Woongarra Coast location; N: near to mangrove; F: far from mangroves. Pairwise test results are provided for significant interactions. Bold: significant $(\mathrm{p}<0.05)$

\begin{tabular}{|lccc|}
\hline Source of variation & df & $\mathrm{p}$ & Pairwise $\mathrm{p}$ \\
\hline Connectivity (C) & 1 & 0.705 & - \\
Status (S) & 1 & $<\mathbf{0 . 0 0 1}$ & - \\
Location (L) & 1 & $<\mathbf{0 . 0 0 1}$ & - \\
Distance to ramp & 1 & $<\mathbf{0 . 0 0 1}$ & - \\
Hard coral cover & 1 & $\mathbf{2 0 . 0 0 1}$ & - \\
C $\times$ S & 1 & $\mathbf{0 . 0 0 4}$ & N: $<\mathbf{0 . 0 0 1}$, F: 0.310 \\
S $\times$ L & 1 & $\mathbf{0 . 0 0 5}$ & GS: $\mathbf{0 . 0 3 9}, \mathbf{W C : ~} \mathbf{0 . 0 0 3}$ \\
C $\times$ L & 1 & $\mathbf{0 . 0 1 0}$ & N: 0.155, F: $<\mathbf{0 . 0 0 1}$ \\
C $\times$ S $\times$ L & 1 & 0.145 & - \\
\hline
\end{tabular}

and mangrove-reef connectivity at the assemblage level, but not at an abundance level. This most likely indicates that, although the influence of mangrovereef connectivity and reserve status differed somewhat across locations for certain species of fish, the effect of reserves and mangrove-reef connectivity on overall fish abundance is the same, regardless of location.

Spatial variation in hard coral cover and the distance of reefs from the nearest boat ramp influenced fish assemblages (hard coral cover, $\mathrm{p}<0.001$; distance to nearest boat ramp, $\mathrm{p}=<0.001$; Table 1 ), but not fish abundances (Tables S4 \& S5 in the Supple-

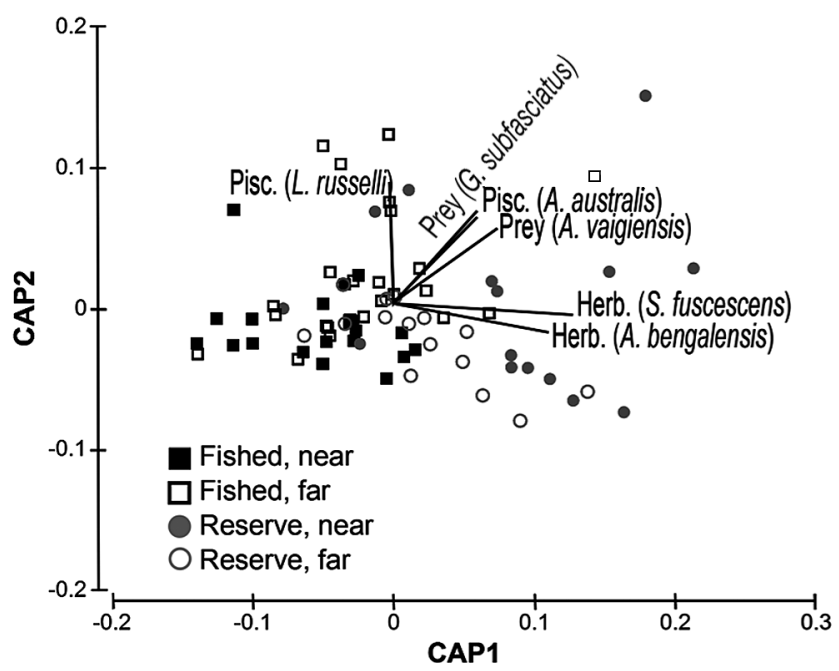

Fig. 2. Constrained canonical analysis of principal co-ordinates (CAP) ordination illustrating the interactive effect of reserves and mangrove-reef connectivity on coral reef fish assemblages $(\delta 2$ [canonical correlation value] $=0.83, \mathrm{~m}$ [no. of axes] $=9$, LoA [level of accuracy for correct allocations to groups] $=48 \%$ ). Vectors represent species that correlate with the canonical axis with Pearson R-values $>0.45$ ment). However, as it did not interact with any of the factors, the effect of hard coral cover and distance to the nearest boat ramp was uniform across all sites. As this effect was only seen at an assemblage level (and not at an abundance level), it indicated that hard coral cover and distance to the nearest boat ramp more strongly influence the species of fish throughout the region (particularly species that either display an affinity with hard coral cover [Wilson et al. 2008] or are harvested in recreational or commercial fisheries [Stuart-Smith et al. 2008]), rather than their abundances.

\section{DISCUSSION}

Conservation outcomes can be improved by incorporating functions like connectivity (Almany et al. 2009, Beger et al. 2010b, Magris et al. 2014), which can enhance the capacity of reserves to promote ecosystem resilience (Nagelkerken et al. 2012). Little is known, however, about the scale over which connectivity is effective across tropical seascapes. Our results confirm that mangrove-reef connectivity can alter the effects of marine reserves on the composition of reef fish assemblages and enhance the abundance of harvested fish species and key functional groups. These findings demonstrate that reserve performance can be enhanced by mangrove-reef connectivity at a scale (i.e. $500 \mathrm{~m}$ ) double that reported as effective elsewhere in the western Pacific Ocean (i.e. $250 \mathrm{~m}$; Olds et al. 2013). This information, when compared to the findings of Olds et al. (2013), suggests that connectivity effects vary among seascapes (sensu Sheaves 2009, Nagelkerken et al. 2015) and may best enhance reserve performance on reefs that are as close to adjacent mangroves as the seascape permits (provided those reefs are within their migratory capabilities).

Depending on the species, there are a variety of mechanisms through which mangrove-reef connectivity may enhance reserve performance, including ontogenetic, tidal and diel feeding movements between mangrove and reef habitats (Krumme 2009). Important species of prey fishes such as the common hardyhead (Atherinomorus vaigiensis) and common silverbiddy (Gerres subfasciatus) make tidal migrations into mangroves to forage and seek shelter from predators (e.g. Laegdsgaard \& Johnson 2001). This may potentially drive the movement of predatory fish such as the yellow-fin bream (Acanthopagrus australis) on hunting forays into the mangroves (sensu Olds et al. 2012b), whereas other predators, such as 


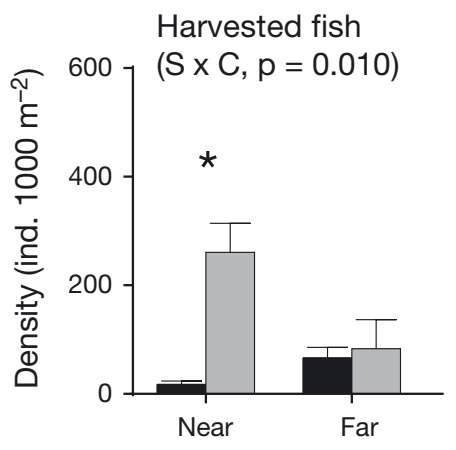

Herbivorous fish

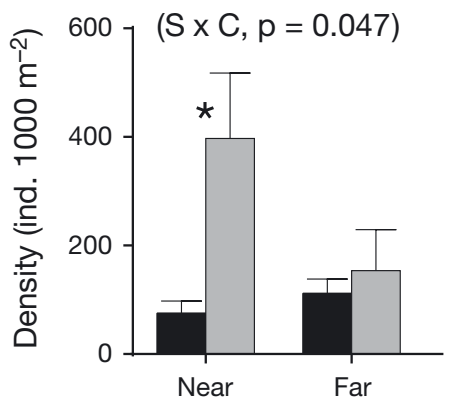

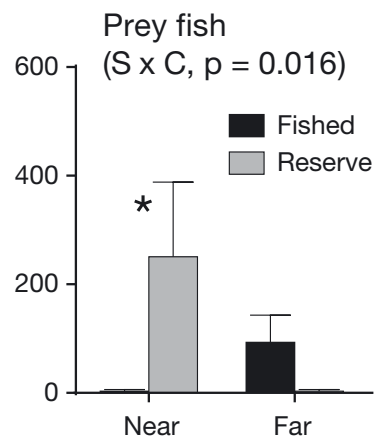

Piscivorous fish

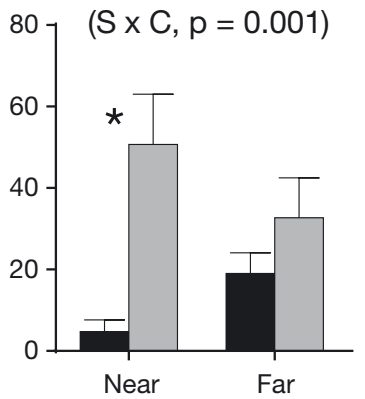

Fig. 3. Density of harvested, herbivorous, prey and piscivorous fish on coral reefs near and far from mangroves in both fished and reserve areas (mean $\pm \mathrm{SE}$ ). ${ }^{*}$ Significant differences between fished and reserve reefs (identified by pairwise tests following PERMANOVA). S: status; C: connectivity. Note the different $y$-axis scales

lutjanids and serranids, may benefit from being close to mangroves as they move ontogenetically from mangrove to reef habitats (e.g. Berkstrom et al. 2013a, Blaber 2000, Sheaves \& Molony 2000). These enhanced abundances of prey fish and commercially important predators in reserves near mangroves, therefore, suggest that they may be benefitting from protection near to their mangrove nursery and feeding areas. Foodweb analyses on subtropical coral

Table 2. Summary of PERMANOVA results examining spatial variation in the abundance of harvested fish species and fish functional groups. Bold: significant $(p<0.05)$. For pairwise test results of significant interactions, see Table S5 in the Supplement. Note: only near-significant variables are included in this table, for results of analysis including all variables, see Table S4 in the Supplement

\begin{tabular}{|lccccc|}
\hline Source of variation & df & \multicolumn{5}{c|}{ p } \\
\cline { 3 - 6 } & & $\begin{array}{c}\text { Harvested } \\
\text { fish }\end{array}$ & $\begin{array}{c}\text { Herbivorous } \\
\text { fish }\end{array}$ & $\begin{array}{c}\text { Piscivorous } \\
\text { fish }\end{array}$ & $\begin{array}{c}\text { Prey } \\
\text { fish }\end{array}$ \\
\hline Connectivity (C) & 1 & 0.999 & 0.542 & 0.728 & 0.772 \\
Status (S) & 1 & $<\mathbf{0 . 0 0 1}$ & $\mathbf{0 . 0 0 6}$ & $\mathbf{0 . 0 0 4}$ & $<\mathbf{0 . 0 0 1}$ \\
Hard coral cover & 1 & 0.081 & - & 0.176 & - \\
Distance to ramp & 1 & 0.081 & $\mathbf{< . 0 0 1}$ & $\mathbf{0 . 0 3 9}$ & $<\mathbf{0 . 0 0 1}$ \\
C $\times$ S & 1 & $\mathbf{0 . 0 1 0}$ & $\mathbf{0 . 0 4 7}$ & $\mathbf{0 . 0 0 1}$ & $\mathbf{0 . 0 1 6}$ \\
\hline
\end{tabular}

reefs have shown an important species of herbivorous rabbitfish (Siganus fuscescens) to consume food sourced from mangroves (Davis et al. 2014), pointing to possible diel feeding forays into the mangroves at high tide. In our study, densities of $S$. fuscescens were an important driver of patterns in fish assemblages on protected reefs near to mangroves (Fig. 2), implying that, for this species at least, protection from fishing on reefs close to mangroves allows the benefit of feeding migrations to be realised. The evaluation of potential mechanisms underlying the effects of connectivity on fish abundance and reserve performance could be further investigated using telemetric tracking of reef species (such as rabbitfish, lutjanids and sparids) thought to use surrounding mangrove habitats (e.g. Pittman et al. 2014).

To incorporate connectivity into conservation planning effectively, we need to understand the importance of different habitats in seascapes, and identify the scale at which they influence species distributions most strongly (Magris et al. 2014, Pittman \& Olds 2014). In Moreton Bay, 3 of the species we studied in Hervey Bay (A. australis, Lutjanus russelli and $S$. fuscescens) were more abundant on reserve reefs within $250 \mathrm{~m}$ of mangroves (Olds et al. 2012b). In Hervey Bay, however, these same species were largely responsible for the differences in fish assemblages between reserve and fished reefs up to $500 \mathrm{~m}$ from mangroves (Fig. 2). This indicates that, for certain fish species, there is a degree of flexibility in their distribution and the scale of important habitat associations among seascapes. Provided cross-habitat distances are within the range of their migratory capabilities (i.e. ontogenetic, tidal, or diel feeding migrations), reef fish that utilise mangroves, such as sea breams (Sparidae), snappers (Lutjanidae) and rabbitfish (Siganidae), may simply position themselves on reefs that are as close to mangroves as the configuration of the seascape allows (Fig. 4). This would allow them to best exploit the benefits of high mangrove-reef connectivity, and, therefore, result in reserve reefs closest to adjacent mangroves being the most effective, at least for species that utilise both habitats.

The importance of seascape structure for scaling connectivity has broad implications for the conservation of organisms that rely on multiple habitats in other heterogeneous coastal seascapes. For example, some fish species respond to different scales of seascape connectivity in seagrass habitats. Invertebrate 
feeders such as grunts (Haemulidae) were most abundant on reefs in the Virgin Islands (Buck Island) that were within $100 \mathrm{~m}$ of seagrass habitats (Kendall et al. 2003); however, in the Virgin Islands (St. John Island), the abundance of grunts was influenced by seagrass up to $1000 \mathrm{~m}$ from reefs (Grober-Dunsmore et al. 2007). Similarly, invertebrate feeders (Lethrinidae) and piscivores (Lutjanidae) were most abundant on reefs in the Indian Ocean (Zanzibar Island) that were within $750 \mathrm{~m}$ of seagrass habitats (Berkstrom et al. 2013b). This implies that seascape structure and composition may play an important role in governing the scale at which reef fish assemblages respond to connectivity.

Connectivity is clearly an important factor influencing the distribution, composition and abundance of fish assemblages. This study demonstrates that mangrove-reef connectivity enhanced reserve effects on coral reef fish assemblages. This positive effect of mangrove-reef connectivity on marine reserve performance in a seascape where large distances separate these habitats broadens the potential application of mangrove-reef connectivity for conservation planning. Where other factors are equal, we suggest that this type of connectivity may be best incorporated into reserve design by simply prioritising the conservation of seascapes where reefs and mangroves are closest.
Acknowledgements. We thank A. Delaforce, A. Martin and K. Martin for field assistance, and M. Zann and the Queensland Department of Environment and Heritage Protection for GIS habitat and reserve layers. Financial support was provided by the Bundaberg Mary Regional Group, Australian Research Council and the Queensland Government.

\section{LITERATURE CITED}

Almany GR, Connolly SR, Heath DD, Hogan JD and others (2009) Connectivity, biodiversity conservation and the design of marine reserve networks for coral reefs. Coral Reefs 28:339-351

Anderson MJ, Willis TJ (2003) Canonical analysis of principal coordinates: a useful method of constrained ordination for ecology. Ecology 84:511-525

Anderson MJ, Gorley RN, Clarke KR (2008) PERMANOVA+ for PRIMER: guide to software and statistical methods. PRIMER-E, Plymouth

Anderson MJ, Crist TO, Chase JM, Vellend M and others (2011) Navigating the multiple meanings of beta diversity: a roadmap for the practicing ecologist. Ecol Lett 14:19-28

Baker R, Sheaves M (2005) Redefining the piscivore assemblage of shallow estuarine nursery habitats. Mar Ecol Prog Ser 291:197-213

Beger M, Linke S, Watts M, Game E, Treml E, Ball I, Possingham HP (2010a) Incorporating asymmetric connectivity into spatial decision making for conservation. Conserv Lett 3:359-368

Beger M, Grantham HS, Pressey RL, Wilson KA and others (2010b) Conservation planning for connectivity across marine, freshwater, and terrestrial realms. Biol Conserv 143:565-575

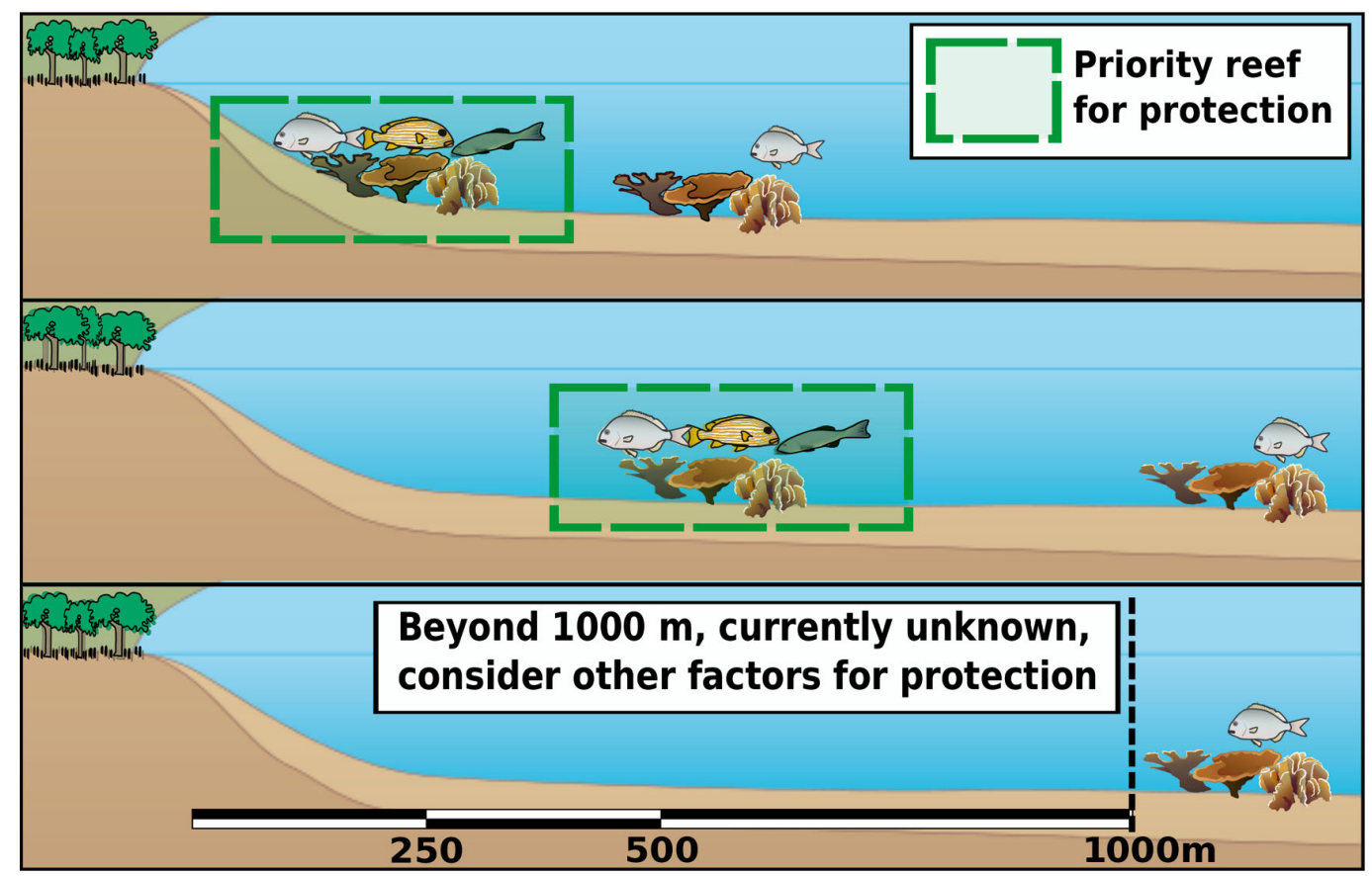

Fig. 4. Generalised conceptual diagram illustrating the importance of scale when incorporating mangrove-reef connectivity into conservation planning. The closest reefs to mangroves in a seascape should be considered the priority for conservation

(where other factors are equal). (Symbols courtesy of the Integration and Application Network, ian.umces.edu/symbols/) 
Berkstrom C, Gullstrom G, Lindborg R, Mwandya AW, Yahya SAS, Katsky N, Nystrom M (2012) Exploring 'knowns' and 'unknowns' in tropical seascape connectivity with insights from East African coral reefs. Estuar Coast Shelf Sci 107:1-21

Berkstrom C, Jörgensen TL, Hellström M (2013a) Ecological connectivity and niche differentiation between two closely related fish species in the mangrove-seagrass-coral reef continuum. Mar Ecol Prog Ser 477:201-215

> Berkstrom C, Lindborg R, Thyresson M, Gullstrom M (2013b) Assessing connectivity in a tropical embayment: fish migrations and seascape ecology. Biol Conserv 166: 43-53

Blaber SJM (2000) Fish faunas and communities. In: Blaber SJM (ed) Tropical estuarine fishes: ecology, exploitation, and conservation. Blackwell Science, Malden, p 40-95

Butler IR, Sommer B, Zann M, Zhao JX, Pandolfi JM (2013) The impacts of flooding on the high-latitude, terrigenoclastic influenced coral reefs of Hervey Bay, Queensland, Australia. Coral Reefs 32:1149-1163

> Calabrese JM, Fagan WF (2004) A comparison-shopper's guide to connectivity metrics. Front Ecol Environ 2: 529-536

Choat JH, Clements KD, Robbins WD (2002) The trophic status of herbivorous fishes on coral reefs. I. Dietary analyses. Mar Biol 140:613-623

> Davis JP, Pitt KA, Fry B, Olds AO, Connolly RM (2014) Seascape-scale trophic links for fish on inshore coral reefs. Coral Reefs 33:897-907

DNPRSR (2012) Great sandy marine park visitor guide. Department of National Parks, Recreation, Sport and Racing, Queensland Government, Brisbane

> Estes JA, Terborgh J, Brashares JS, Power ME and others (2011) Trophic downgrading of planet earth. Science 333:301-306

Ferrell D, Sumpton W (1997) Assessment of the fishery for snapper (Pagrus auratus) in Queensland and New South Wales. QLD Department of Primary Industries, Deception Bay

Froese R, Pauly D (2000) FishBase 2000: concepts, design and data sources. ICLARM, Los Baños, Laguna

Gillanders BM, Able KW, Brown JA, Eggleston DB, Sheridan PF (2003) Evidence of connectivity between juvenile and adult habitats for mobile marine fauna: an important component of nurseries. Mar Ecol Prog Ser 247:281-295

- Grober-Dunsmore R, Frazer TK, Lindberg WJ, Beets J (2007) Reef fish and habitat relationships in a Caribbean seascape: the importance of reef context. Coral Reefs 26: 201-216

Grober-Dunsmore R, Pittman SJ, Caldow C, Kendall MS, Frazer TK (2009) A landscape ecology approach for the study of ecological connectivity across tropical marine seascapes. In: Nagelkerken I (ed) Ecological connectivity among tropical coastal ecosystems. Springer, New York, NY, p 493-530

Haywood MDE, Kenyon RA (2009) Habitat shifts by decapods - an example of connectivity across tropical marine ecosystems. In: Nagelkerken I (ed) Ecological connectivity among tropical coastal ecosystems. Springer, New York, NY, p 229-269

> Hodgson JA, Thomas CD, Wintle BA, Moilanen A (2009) Climate change, connectivity and conservation decision making: back to basics. J Appl Ecol 46:964-969

Huijbers CM, Connolly RM, Pitt KA, Schoeman DS and others (2015) Conservation benefits of marine reserves are undiminished near coastal rivers and cities. Conserv Lett. doi:10.1111/conl.12128

> Hyndes GA, Nagelkerken I, McLeod R, Connolly RM, Lavery P, Vanderklift M (2014) Mechanisms and ecological role of carbon transfer within coastal seascapes. Biol Rev Camb Philos Soc 89:232-254

Igulu MM, Nagelkerken I, Dorenbosch M, Grol MGG and others (2014) Mangrove habitat use by juvenile reef fish: meta-analysis reveals that tidal regime matters more than biogeographic region. PLoS ONE 9:e114715. doi: 10.1371/journal.pone.0114715.

> Kendall MS, Christensen JD, Hillis-Starr Z (2003) Multiscale data used to analyze the spatial distribution of French grunts, Haemulon flavolineatum, relative to hard and soft bottom in a benthic landscape. Environ Biol Fishes 66:19-26

$>$ Kohler KE, Gill SM (2006) Coral Point Count with Excel extensions (CPCe): a Visual Basic program for the determination of coral and substrate coverage using random point count methodology. Comput Geosci 32:1259-1269

Krumme U (2009) Diel and tidal movements by fish and decapods linking tropical coastal ecosystems. In: Nagelkerken I (ed) Ecological connectivity among tropical coastal ecosystems. Springer, New York, NY, p 271-324

> Laegdsgaard P, Johnson CR (2001) Why do juvenile fish utilise mangrove habitats? J Exp Mar Biol Ecol 257: 229-253

> Lindenmayer D, Hobbs RJ, Montague-Drake R, Alexandra J and others (2008) A checklist for ecological management of landscapes for conservation. Ecol Lett 11:78-91

Magris RA, Pressey RL, Weeks R, Ban NC (2014) Integrating connectivity and climate change into marine conservation planning. Biol Conserv 170:207-221

McCook LJ, Almany GR, Berumen ML, Day JC and others (2009) Management under uncertainty: guide-lines for incorporating connectivity into the protection of coral reefs. Coral Reefs 28:353-366

> Mora C, Treml EA, Roberts J, Crosby K, Roy D, Tittensor DP (2012) High connectivity among habitats precludes the relationship between dispersal and range size in tropical reef fishes. Ecography 35:89-96

> Mumby PJ, Hastings A (2008) The impact of ecosystem connectivity on coral reef resilience. J Appl Ecol 45:854-862

Mumby PJ, Edwards AJ, Arias-Gonzalez JE, Lindeman KL and others (2004) Mangroves enhance the biomass of coral reef fish communities in the Caribbean. Nature 427:533-536

Nagelkerken I (2009) Evaluation of nursery function of mangroves and seagrass beds for tropical decapods and reef fishes: patterns and underlying mechanisms. In: Nagelkerken I (ed) Ecological connectivity among tropical coastal ecosystems. Springer, New York, NY, p 357-399

> Nagelkerken I, Grol MGG, Mumby PJ (2012) Effects of marine reserves versus nursery habitat availability on structure of reef fish communities. PLoS ONE 7:e36906

Nagelkerken I, Sheaves M, Baker R, Connolly RM (2015) The seascape nursery: a novel spatial approach to identify and manage nurseries for coastal marine fauna. Fish Fish 16:362-371

> Nystrom M, Folke C (2001) Spatial resilience of coral reefs. Ecosystems 4:406-417

Olds AD, Pitt KA, Maxwell PS, Connolly RM (2012a) Synergistic effects of reserves and connectivity on ecological resilience. J Appl Ecol 49:1195-1203

Olds AD, Connolly RM, Pitt KA, Maxwell PS (2012b) Habitat 
connectivity improves reserve performance. Conserv Lett 5:56-63

Olds AD, Albert S, Maxwell PS, Pitt KA, Connolly RM (2013) Mangrove-reef connectivity promotes the effectiveness of marine reserves across the western Pacific. Glob Ecol Biogeogr 22:1040-1049

Peterson BJ, Valentine JF, Heck KL (2013) The snappergrunt pump: habitat modification and facilitation of the associated benthic plant communities by reef-resident fish. J Exp Mar Biol Ecol 441:50-54

Pittman SJ, McAlpine CA (2003) Movements of marine fish and decapod crustaceans: process, theory and application. Adv Mar Biol 44:205-294

Pittman SJ, Olds AD (2014) Seascape ecology of fishes on coral reefs. In: Mora C (ed) Ecology of fishes on coral reefs. Cambridge University Press, Cambridge

Pittman SJ, Monaco ME, Friedlander AM, Legare B and others (2014) Fish with chips: tracking reef fish movements to evaluate size and connectivity of Caribbean marine protected areas. PLoS ONE 5:e96028, doi:10.1371/journal. pone.0096028

Sheaves M (2009) Consequences of ecological connectivity: the coastal ecosystem mosaic. Mar Ecol Prog Ser 391: $107-115$

Sheaves M, Molony B (2000) Short-circuit in the mangrove food chain. Mar Ecol Prog Ser 199:97-109

Sheaves M, Baker R, Nagelkerken I, Connolly RM (2015) True value of estuarine and coastal nurseries for fish:

Editorial responsibility: Janet Ley,

St. Petersburg, Florida, USA incorporating complexity and dynamics. Estuar Coast 38: 401-414

Soons MB, Heil GW, Nathan R, Katul GG (2004) Determinants of long-distance seed dispersal by wind in grasslands. Ecology 85:3056-3068

Stuart-Smith RD, Barrett NS, Crawford CM, Frusher SD, Stevenson DG, Edgar GJ (2008) Spatial patterns in impacts of fishing on temperate rocky reefs: Are fish abundance and mean size related to proximity to fisher access points? J Exp Mar Biol Ecol 365:116-125

Warfe DM, Pettit NE, Magierowski RH, Pusey BJ, Davies PM, Douglas MM, Bunn SE (2013) Hydrological connectivity structures concordant plant and animal assemblages according to niche rather than dispersal processes. Freshw Biol 58:292-305

Wedding LM, Lepczyk CA, Pittman SJ, Friedlander AM, Jorgensen S (2011) Quantifying seascape structure: extending terrestrial spatial pattern metrics to the marine realm. Mar Ecol Prog Ser 427:219-232

> Wilson SK, Fisher R, Pratchett MS, Graham NAJ and others (2008) Exploitation and habitat degradation as agents of change within coral reef fish communities. Glob Change Biol 14:2796-2809

Zann M (2012) The use of remote sensing and field validation for mapping coral communities of Hervey Bay and the Great Sandy Strait and implications for coastal planning policy. M. Phil. thesis, University of Queensland, St Lucia, QLD

Submitted: January 20, 2015; Accepted: March 24, 2015

Proofs received from author(s): April 29, 2015 